\title{
Participacija učenika putem primjene i procjene uspješnosti MAPS tehnike osobno usmjerenog planiranja - studija slučaja
}

Tanja Opačak*

tanja.opacak@gmail.com

Aleksandra Krampač Grljušićc*

a.krampac@yahoo.com

Marija Lončarićs***

marija.loncaric92@gmail.com https://doi.org/10.31192/np.17.2.7

UDK: 37:159.922.76-056.313

Prethodno priopćenje /

Preliminary communication

Primljeno: 22. siječnja 2019.

Prihvaćeno: 8. lipnja 2019.

Polazeći od koncepta inkluzivnog obrazovanja u kojem je aktivna participacija učenika s teškoćama u razvoju i individualizirana podrška od velikog značenja $z a$ odgojno obrazovni uspjeh $i$ osobno zadovoljstvo učenika, primijenili smo $i$ pokušali procijeniti uspješnost MAPS tehnike osobno usmjerenog planiranja za učenika 5. razreda osnovne škole. Istraživanje je provedeno kao studija slučaja za jednog učenika s teškoćama u razvoju, sudjelovalo je 14 sudionika, 10 odraslih osoba i četiri učenika 5. razreda, od kojih je jedan učenik s teškoćama. Podaci su prikupljeni intervjuima sa svim sudionicima te opservacijom učenika za kojega je MAPS tehnika primijenjena.

Objedinjavanjem i kvalitativnom obradom podataka dobili smo jasniji uvid u subjektivna iskustva $i$ emocije sudionika koja su razvrstana u pet tematskih područja. Uočen je pozitivan učinak primjene osobno usmjerenog planiranja na dobrobit i kvalitetu života učenika s teškoćama u razvoju (veća prihvaćenost učenika u razrednom okruženju, razvoj učenikovih socijalnih $i$ komunikacijskih vještina, učvršćivanje prijateljstva, druženje u slobodno vrijeme), što može pridonijeti lakšoj prilagodbi učenika na zahtjeve koje postavljaju viši razredi osnovne škole. Provedeno istraživanje ukazuje na važnost primjene MAPS tehnike kao načina individualizirane potpore te istovremeno ističe važnost partici-

* Tanja Opačak, doktorandica, Edukacijsko-rehabilitacijski fakultet Sveučilišta u Zagrebu, Znanstveno-učilišni kampus Borongaj, Borongajska cesta 83f, 10000 Zagreb.

* Dr. sc. Aleksandra Krampač-Grljušić, ravnateljica Osnovna škola Ljudevita Gaja, Osijek, Krstova ulica 99, HR-31000 Osijek.

***: Marija Lončarić, mag. rehab. educ., stručni suradnik edukator-rehabilitator, Osnovna škola »Žuti brijeg«, Zagreb, Vrtnjakovečka 8, HR-10000 Zagreb. 
pacije učenika s teškoćama u razvoju i njegovih vršnjaka u procesu planiranja $i$ provodenju inkluzivne prakse u odgojno-obrazovnom sustavu.

Ključne riječi: inkluzivno obrazovanje, MAPS tehnika, osobno usmjereno planiranje, participacija.

\section{Uvod}

Aktivno sudjelovanje djece (participacija) u obrazovanju pretpostavlja brojne odgovornosti koje se dijele između djece i odraslih u školi. Inkluzivno obrazovanje je konceptualno jednostavno, no nije uvijek jednostavno provedivo. Polazište i okvir za ostvarivanje prava djeteta na inkluzivno obrazovanje i participaciju je Konvencija UN-a o pravima djeteta. ${ }^{1} \mathrm{U}$ ovom međunarodnom, pravno obvezujućem dokumentu, participacija se spominje na tri načina: ${ }^{2}$ a) shvaćena je kao jedno od četiri temeljna načela na kojem se Konvencija temelji; b) u kontekstu participativnih prava i c) kao zaseban članak (čl. 12.) u kojem se navodi da će države stranke

»osigurati djetetu koje je sposobno oblikovati svoje osobno mišljenje, pravo na slobodno izražavanje svog mišljenja o svim pitanjima koja se na njega odnose i uvažavati to mišljenje u skladu s dobi i zrelošću djeteta «. ${ }^{3}$

Svako dijete ima pravo na obrazovanje koje treba biti usmjereno prema punom razvoju njegove osobnosti, nadarenosti, duševne i tjelesne sposobnosti. ${ }^{4}$ Učenici s teškoćama u razvoju ostvaruju pravo na primjerene programe školovanja i primjerene oblike podrške tijekom školovanja. ${ }^{5} \mathrm{U}$ UN-ovoj Konvenciji o pravima osoba s invaliditetom, ${ }^{6} \mathrm{u}$ čl. 24 posebno se ističe nužnost razumne prilagodbe i pružanja potrebne pomoći svakom djetetu radi djelotvornog obrazovanja, te pružanje djelotvornih individualiziranih mjera potpore u okruženjima koja najviše pridonose punom razvoju njihovih potencijala u svrhu inkluzije. Jedan od oblika suvremenog modela individualizirane potpore jest osobno usmjereno planiranje. Osobno usmjereno planiranje je često izazov

${ }^{1}$ Usp. UN KONVENCIJA O PRAVIMA DJETETA (1989) http://www.unicef.hr/wp-content/ uploads/2017/05/Konvencija_20o_20pravima_20djeteta_full.pdf (22.01.2019), 7.

${ }^{2}$ Usp. S. MILIĆ, J. MAROJEVIĆ, Implementacija koncepta dječjih prava u crnogorskom obrazovnom sustavu, Pedagogijska istraživanja, 11 (2014) 1, 123-139, 126.

${ }^{3}$ Usp. UN Konvencija o pravima djeteta..., 7.

${ }^{4}$ Usp. isto, 11.

${ }^{5}$ Usp. ZAKON O ODGOJU I OBRAZOVANJU U OSNOVNOJ I SREDNJOJ ŠKOLI, Narodne novine 87/08, 86/09, 92/10, 105/10, 90/11, 5/12, 16/12, 86/12, 126/12, 94/13, 152/14, 07/17, 68/18, https://narodne-novine.nn.hr/clanci/sluzbeni/2018_07_68_1398.html (22.01.2019); PRAVILNIK O OSNOVNOŠKOLSKOM I SREDNJOŠKOLSKOM ODGOJU I OBRAZOVANJU UČENIKA S TEŠKOĆAMA U RAZVOJU, Narodne novine, 23/91, 24/15, https://narodne-novine.nn.hr/clanci/sluzbeni/2015_03_24_510.html (22.01.2019).

${ }^{6}$ Usp. UN KONVENCIJA O PRAVIMA OSOBA S INVALIDITETOM, (2006), http://posi.hr/ wp-content/uploads/2018/02/Zakon_o_Konvenciji_o_pravima_OSI.pdf (22.01.2019). 
postojećim sustavima i značajno se razlikuje od institucionalnog planiranja jer usvaja održive i kreativne pristupe koji su sistematični i strukturirani. ${ }^{7}$ Može se provoditi s osobama svih životnih dobi. ${ }^{8}$ Trenutačno je vrlo malo objavljenih istraživanja koja uključuju praksu osobno usmjerenog planiranja. ${ }^{9}$ Postoje mnogi modeli osobno usmjerenog planiranja, a jedan od njih je Akcijski plan za normalizaciju Mc Gill Action Planning System, poznatiji kao MAPS. ${ }^{10}$

\section{Teorijska polazišta}

Svako dijete $\mathrm{s}$ teškoćama u razvoju treba voditi ispunjen i pristojan život $\mathrm{u}$ uvjetima koji jamče dostojanstvo, jačaju djetetovo oslanjanje na vlastite snage i olakšavaju njegovo djelatno sudjelovanje u zajednici. ${ }^{11}$ Cilj je svakom djetetu omogućiti stjecanje najviše razine znanja, sposobnosti i vještina u skladu s njegovim mogućnostima za samostalan i uspješan život, ispunjen učenjem, radom, samopoštovanjem i općim zadovoljstvom. ${ }^{12}$ Planiranje individualiziranoga kurikuluma počiva na realno postavljenim ciljevima, polazi od učenikovih sklonosti, prepoznatih mogućnosti, a sadržava i podatke o potrebnim oblicima potpore, tijeku provođenja potpore te postignutim ishodima. ${ }^{13}$

Iščitavajući literaturu o osobno usmjerenom planiranju može se jasno uvidjeti da je taj pristup usmjeren na vrline, kapacitete, snove i želje osobe ${ }^{14}$ te je za proces razvoja osobnog kurikuluma prikladno koristiti neke od tehnika osobno usmjerenog planiranja. ${ }^{15}$ MAPS je tehnika pomoću koje se vizualizira željena

\footnotetext{
7 Usp. S.A. RASHEED, C. FORE, S. MILLER, Person-Centered Planning. Practices, Promises, and Provisos. The Journal for Vocational Special Needs Education, 28 (2006) 3, 47-51; A. KRAMPAČ-GRLJUŠIĆ, Socijalno-emocionalna obilježja učenika inkluzivnih razreda $i$ primjena modela krugova prijatelja, (Doktorski rad), Zagreb, Edukacijsko rehabilitacijski fakultet, 2015, 17.

${ }^{8}$ Usp. A. KRAMPAČ-GRLJUŠIĆ, V. MIHANOVIĆ, Teorijski i praktični prikaz primjene alata osobno usmjerenog planiranja, u: V. Đurek, (ur.), Zbornik radova 8. kongresa s medunarodnim sudjelovanjem. Uključivanje i podrška u zajednici, Varaždin, Savez defektologa Hrvatske, 2010, 35-42, 40.

${ }^{9}$ Usp. isto, 37.

${ }^{10} \mathrm{~J}$. LESIČKI, Osobno usmjeren pristup pri individualnom planiranju za osobe s intelektualnim teškoćama u institucijskim uvjetima, Ljetopis socijalnog rada, 18 (2011) 3, 555-577, 561.

${ }^{11}$ Usp. UN, Konvencija o pravima djeteta, 9-10.

${ }^{12}$ Usp. MINISTARSTVO ZNANOSTI, OBRAZOVANJA I ŠPORTA RH, Nacionalni okvirni kurikulum za predškolski odgoj i obrazovanje te opće obvezno i srednjoškolsko obrazovanje, (2011), http://mzos.hr/datoteke/Nacionalni_okvirni_kurikulum.pdf (22.01.2019), 272.

${ }^{13}$ Usp. isto, 273.

${ }^{14}$ Usp. B. ROZMAN, Osobno usmjereno planiranje, Zagreb, Centar za obrazovanje odraslih Validus, 2013, 29.

${ }^{15}$ Usp. MZO, Okvir za poticanje i prilagodbu iskustava učenja te vrednovanje postignuća djece i učenika s teškoćama, (2016), https://mzo.hr/sites/default/files/migrated/nacionalni_ dokument-okvir_za_poticanje_i_prilagodbu_iskustava_ucenja-vrednovanje_postignuca_ djece-i-ucenika_s_teskocama.pdf (22.01.2019), 26.
} 
budućnost za pojedinca i snovi pretvaraju u stvarnost. ${ }^{16}$ Omogućava učeniku, koji je u središtu procesa, uključivanje u inkluzivno okruženje. ${ }^{17}$ Cilj MAPS-a je pronaći načine kako potpuno uključiti učenika u skupinu vršnjaka u školi kroz pomno izrađeni akcijski plan. ${ }^{18} \mathrm{U}$ literaturi se navodi da se ova tehnika $\mathrm{u}$ radu $\mathrm{s}$ učenicima s teškoćama u razvoju primjenjuje posebice u razdobljima koja su za njih od posebnog značenja (upis u prvi razred, mijenjanje škole, prijelaz u predmetnu nastavu ili u srednju školu, zaposlenje...). Sve to pred njih postavlja nove zahtjeve i iziskuje mnogo truda svih sudionika kako bi se učenici što bolje prilagodili novoj situaciji, a svi sudionici MAPS tehnike imaju važnu ulogu u procesu planiranja podrške radi što boljeg upoznavanja učenika da bi se započeo i potaknuo proces promjene. ${ }^{19} \mathrm{U}$ procesu sudjeluje učenik $\mathrm{s}$ teškoćama u razvoju i osobe iz njegova prirodnog i neposrednog okruženja koje ga dobro poznaju. Dijeleći informacije o tijeku njegova razvoja, jakim stranama, potrebama, željama i strahovima podupire se prijateljstvo među vršnjacima i unapređenje kvalitete učenja i poučavanja. ${ }^{20}$

MAPS tehnika provodi se u osam koraka: U prvom koraku, moderator postavlja pitanja sudionicima navodeći ih na razmišljanje i tražeći odgovore koji će pomoći sudionicima sagledati »gdje se nalaze i kamo trebaju ići«. Drugi korak omogućuje osobi za koju se izrađuje plan i onima koji tu osobu poznaju dulje vrijeme da opišu što se događalo s tom osobom u prošlosti. Treći korak je »sanjanje«, gdje je osoba pozvana podijeliti svoj san s drugima, a drugi sudionici mogu pridonijeti tom snu svojim idejama. Četvrti korak omogućava skupini i pojedincu da prepoznaju i izraze svoje strahove putem iskazivanja »noćnih mora« i mogućnost suočavanja i odmaka od njih. Peti korak je značajan afirmativni proces gdje sudionici pokušavaju, odgovarajući na pitanja moderatora, riječima sažeti lik te osobe. Nadalje, u šestom koraku skupina iznosi pozitivne karakteristike, snagu i talente osobe za koju se planiranje provodi. U sedmom koraku sudionici razmišljaju o osobama i resursima potrebnim za podršku osobi za koju i s kojom se planiranje provodi, a da bi ostvarila svoje snove i riješila se »noćnih mora«. Zaključno i vrlo logično osmi je korak konkretizacija ideja (tko, što kada, kako) u odnosu na »realizaciju snova«, odnosno konkretno zacrtane ciljeve. ${ }^{21}$

Iz navedenog je vidljivo da je u centru procesa učenik za kojeg se provodi planiranje te mu se nudi prilika da izrazi što je to za njega važno i što on želi ${ }^{22}$

\footnotetext{
${ }_{16}^{16}$ Usp. B. Rozman, Osobno usmjereno..., 36.

${ }^{17}$ Usp. MZO, Okvir za poticanje..., 26.

${ }^{18}$ Usp. Krampač-Grljušić, Mihanović, Teorijski i praktični..., 35-42, 38.

${ }^{19}$ Primjerice, A. KRAMPAČ, GRLJUŠIĆ, I. MARINIĆ, Posebno dijete. Priručnik za učitelje u radu s djecom s posebnim obrazovnim potrebama, Osijek, Grafika, 2007, 83-90; MZO, Okvir za poticanje..., 26.

${ }^{20}$ Usp. Krampač Grljušić, Marinić, Posebno dijete..., 83-90, 84.

${ }^{21}$ Usp. Krampač-Grljušić, Mihanović, Teorijski i praktični..., 39.

${ }^{22}$ Usp. Krampač Grljušić, Marinić, Posebno dijete..., 84.
} 
i da se što bolje pripremi i upozna s izazovima u budućnosti. ${ }^{23} \mathrm{Na}$ taj se način MAPS tehnika logično nameće kao idealna platforma za ostvarivanje prava djeteta s teškoćama u razvoju i njegovih vršnjaka na participaciju. Mogućnost da učenik s teškoćama sam odabire sudionike MAPS procesa, značajan je doprinos ostvarivanju ovog važnog prava. Participacijski kontinuum se proteže od informiranja, savjetovanja, preko ko-produkcije (planova), suodlučivanja do kontrole nad donošenjem odluka. ${ }^{24}$ Svaki način uključivanja djece u proces planiranja, provedbe i evaluacije programa poželjan je korak k ostvarivanju prava na sudjelovanje i postizanje učinkovite obrazovne inkluzije.

Samim pristupom osobno usmjerenog planiranja nastoji se pridonijeti većoj uključenosti pojedinca u zajednicu, razvoju i održavanju prijateljstva s vršnjacima, razvoju samoodlučnosti izražavanjem preferencija i izvora, pružanju mogućnosti za dostojanstven doprinos zajednici te stjecanju funkcionalnih vještina..$^{25}$

\section{Empirijski pristup istraživanom problemu}

$\mathrm{Na}$ nacionalnoj razini vrlo je malo objavljenih istraživanja o primjeni i uspješnosti primjene osobno usmjerenog planiranja u radu s učenicima s teškoćama u razvoju. Iz svjetskih istraživanja vidljivo je da na temelju dogovorenog akcijskog plana učenici s teškoćama u razvoju produbljuju socijalne odnose, osjećaju se zadovoljnije jer uviđaju da svojim snagama mogu doprinijeti drugima $^{26}$ te samim time stvaraju bolju sliku o sebi zbog doprinosa zajednici. ${ }^{27}$ Izvještaj Kansas State Board of Education ${ }^{28}$ ukazuje da se učenici s teškoćama u razvoju, koji su uključeni u redovite školske ustanove, lakše uključuju u zajednicu i prihvaćaju svoje uloge u njoj, dok Institute for Health Research ${ }^{29}$ izvještava da osobno usmjereno planiranje pridonosi poboljšanju kvalitete života kod učenika s teškoćama u učenju.

\footnotetext{
${ }^{23}$ Usp. KANSAS STATE BOARD OF EDUCATION, MAPS. A Plan for Including all Children in Schools 1990, https://files.eric.ed.gov/fulltext/ED355752.pdf (22.01.2019), 17.

${ }^{24}$ Usp. K. MORTIER i sur., Participatie van kinderen met een beperking en hun ouders in de realisatie van inclusief onderwijs, Tijdschrift Voor Orthopedagogiek, 51 (2012) 6, 319 -330, 320.

${ }^{25}$ Usp. LJ. IGRIĆ i sur, Osnove edukacijskog uključivanja. Škola po mjeri svakog djeteta je moguća, Zagreb, Školska knjiga, 2015, 169.

${ }^{26}$ Usp. C. DINGWALL, K. KEMP, B. FOWKE, Creating a Good Life in Community. A Guide on Person-Directed Planning, Ontario, Ministry of Community and Social Services, 2006, 5.

${ }^{27}$ Usp. H. GARNER, L. DIETZ, Person-centered Planning. Maps and Paths to the Future, (27.09.2017), http://www.ttac.odu.edu/Articles/person.html (22.01.2019), 2.

${ }^{28}$ Usp. Kansas State Board of Education, MAPS. A Plan for..., 17.

${ }^{29}$ Usp. Krampač-Grljušić, Socijalno-emocionalna..., 2.
} 


\section{Cilj istraživanja}

Cilj istraživanja je bio primjena MAPS tehnike u radu s učenikom $s$ teškoćama u razvoju te iz perspektive sudionika procijeniti primjenu i uspješnost MAPS tehnike koji pridonosi participaciji učenika s teškoćama u razvoju i njegovih vršnjaka u procesu planiranja i provođenju inkluzivne prakse u odgojno-obrazovnom sustavu. U skladu s ciljem postavljena su sljedeća istraživačka pitanja:

1. Kako su se sudionici osjećali tijekom ostvarivanja dogovorenog akcijskog plana?

2. Kako sudionici shvaćaju vlastite uloge pri ostvarivanju akcijskog plana?

3. Koji doprinos akcijskog plana prepoznaju sudionici?

4. Kako sudionici procjenjuju ostvarivanje akcijskog plana?

5. Kako sudionici doživljavaju ostvarenost vlastitih očekivanja u odnosu na akcijski plan?

\section{Metodologija}

S obzirom na to da je istraživanje zahtijevalo prikupljanje podataka iz različitih izvora (MAPS profil učenika, intervjui i opservacija), studija slučaja se nametnula kao najprimjerenija metoda za njegovu provedbu. Odabrali smo je i s obzirom da se ova metoda u literaturi navodi kao empirijsko istraživanje usmjereno na proučavanje stanovitog fenomena unutar njegova stvarnog životnog konteksta koje koristimo kada namjerno želimo obuhvatiti kontekstualne uvjete za koje vjerujemo da bi mogli biti relevantni za fenomen koji istražujemo. ${ }^{30}$ U literaturi nalazimo i tvrdnju da se

»studija slučaja može tretirati kao pristup, a ne samo kao metoda, jer je terensko istraživanje (najčešće) zasnovano na primjeni dubinskog intervjua, promatranja sa sudjelovanjem $\mathrm{i} / \mathrm{ili}$ neke dodatne tehnike istraživanja ${ }^{31}{ }^{31}$

Uobičajeni načini dolaska do informacija koje se prikazuju u studiji slučaja su: analiza dokumentacije, intervju, opservacija i sl.

\footnotetext{
${ }^{30}$ Usp. R. K. YIN, Studija slučaja - dizajn i metode, Zagreb, Fakultet političkih znanosti Sveučilišta u Zagrebu, 2007, 24-26.

${ }^{31}$ Usp. I. TOMIĆ-KOLUDROVIĆ, A. LEBURIĆ, Sociologija životnog stila. Prema novoj metodološkoj strategiji, Zagreb, Naklada Jesenski i Turk - Hrvatsko sociološko društvo, 2002, 226.
} 


\subsection{Uzorak sudionika}

S obzirom na to da je istraživanje studija slučaja jednog učenika s teškoćama u razvoju, učenik je sudionik koji je u centru procesa planiranja, a ostali sudionici su obuhvaćeni istraživanjem jer dobro poznaju učenika i mogu ponuditi važne informacije za što bolje upoznavanje učenika i kvalitetniju procjenu učinkovitosti MAPS tehnike. U istraživanju je stoga korišten namjeran uzorak sudionika koji je usmjeren na pronalaženje i uključivanje najinformativnijih sudionika koji imaju veliko iskustvo s predmetom istraživanja. ${ }^{32}$ Ukupno je u istraživanju sudjelovalo 14 ispitanika, od čega 10 odraslih osoba u različitim ulogama: roditelji, učitelji, stručni suradnici škole i pomoćnik u nastavi te četiri učenika 5. razreda (od kojih učenik s teškoćama u razvoju za kojeg se planiranje provodilo).

Podatci o učeniku: Dječak star 12 godina polaznik 5. razreda. Srdačan je, dobrodušan, organiziran, marljiv. Voli rutine i rituale. Živi u cjelovitoj četveročlanoj obitelji. Rani psihomotorni razvoj protekao je uz manja odstupanja. U četvrtoj godini života stručnjaci su utvrdili usporen razvoj govora, ADHD, graničan globalni intelektualni razvoj, teškoće u socijalnoj interakciji i komunikaciji te u održavanju pažnje i komunikacije. Učenik je bio uključen u predškolsku ustanovu od tri godine. Teže se uklapao u vršnjačku skupinu i njihove aktivnosti. Školovanje mu je bilo odgođeno. Uz podršku pomoćnika u nastavi i primjereni program školovanja učenik postiže odličan uspjeh. Velik interes pokazuje za nastavu engleskog jezika i povijesti. Zanimaju ga elektronički mediji, glazba i ples. Ima izvrsno kratkotrajno pamćenje, komunikacija mu je intencijska. U govoru su prisutne ponavljajuće fraze i eholalija. Koristi se i gestama i vođenjem. Potrebno mu je vodstvo odrasle osobe pri upoznavanju i istraživanju okoline. U interakciju s vršnjacima stupa samo na inicijativu vršnjaka. Pri iniciranju interakcije potrebna je potpora odraslog da bi se ona održala i razvijala.

\subsection{Tijek istraživanja, prikupljanje i obrada podataka}

Prije provedbe istraživanja, dobivena je pisana suglasnost svih sudionika za provođenje istraživanja kao i suglasnost Ministarstva znanosti i obrazovanja, nakon čega je započelo planiranje samog procesa. Dogovoreno je mjesto i vrijeme provedbe MAPS tehnike, podijeljene su uloge sudionicima te je osigurana hrana i piće da bi atmosfera bila neformalna i ugodna. Svaki sudionik je dobio karticu s imenom i svojom ulogom, nakon čega je započela provedba. Proces MAPS-a je vodio voditelj-facilitator, a grafički facilitator je zapisivao izrečeno. Jedna od značajki MAPS tehnike je i donošenje konkretnog akcijskog plana

\footnotetext{
${ }^{32}$ M. B. MILES, A. M. HUBERMAN, Qualitative Data Analysis. An expanded Sourcebook, Thousand Oaks, CA, Sage Publications, 1994, 27-34.
} 
s realnim i ostvarivim ciljevima i jasno definiranom podrškom za učenika s teškoćama u razvoju..$^{33}$

\section{MAPS akcijski plan}

$\mathrm{S}$ obzirom na karakteristike učenika s teškoćama u razvoju i njegove potrebe, kao rezultat primjene MAPS tehnike donesen je akcijski plan s dva cilja: 1. druženje s vršnjacima izvan škole; 2 . jasna struktura pitanja pri usmenim i pismenim provjerama znanja. Svi sudionici su dobili svoje uloge u realizaciji akcijskog plana. Realizaciji drugog cilja se pristupilo tako da su na sjednici Učiteljskog vijeća predmetni učitelji obaviješteni o navedenoj prilagodbi te su je odmah počeli primjenjivati u radu. Naše istraživanje je bilo usmjereno na ostvarivanje prvog cilja MAPS akcijskog plana - druženje s vršnjacima izvan škole. Ostvarivanje dogovorenog MAPS akcijskog plana trajalo je pet mjeseci (drugo školsko polugodište).

\section{Intervju i opservacija}

Tijekom provedbe akcijskog plana prikupljali su se podatci važni za studiju slučaja primjenom intervjua i opservacijom. Tijekom drugog polugodišta organizirano je sedam vršnjačkih susreta (primjerice, posjet zoološkom vrtu, proslava rođendana, odlazak u kino, igranje s vršnjacima kod kuće itd.). Nakon svakog organiziranog vršnjačkog susreta intervjuirani su roditelji učenika, vršnjaci, učitelji i pomoćnik u nastavi. Provedbom intervjua smo nastojali ostvariti jasniji pristup istraživanoj temi putem bilježenja osjećaja, mišljenja i doživljaja učenika u inkluzivnoj školi, njihovih vršnjaka, roditelja, učitelja i pomoćnika u nastavi. Intervju je provodio jedan istraživač (edukator-rehabilitator) u svom uredu da sudionici ne bi bili ometani vanjskim faktorima. Za potrebe istraživanja osmišljen je polustrukturirani intervju koji se sastojao od devet pitanja. Opservacija učenika s teškoćama u razvoju te njegovih vršnjaka tijekom nastave, školskih aktivnosti i odmora provedena je radi dopune podataka prikupljenih intervjuima. Opservaciju su, s obzirom na blizinu predmetu istraživanja iz pozicije promatrača, provodili pomoćnik u nastavi i stručni suradnik edukator rehabilitator, koristeći posebno formirane obrasce praćenja promjena $u$ ponašanju tijekom nastave i tijekom odmora. Bilješke ponašanja su se unosile u obrasce prikladnih i neprikladnih ponašanja i osjećanja od strane učenika koji je u središtu procesa i njegovih vršnjaka. Opservacija se obavljala pod svakim nastavnim predmetom i školskim aktivnostima (svaki tjedan jedan predmet) te pod školskim odmorom (uvijek isti odmor). Ukupno je provedeno 13 opservacija tijekom nastavnih sati i školskih aktivnosti te 18 opservacija tijekom školskih

\footnotetext{
${ }^{33}$ Detaljnije o provedbi i više o smjernicama za što uspješniju provedbu MAPS-a u: M. FOREST, J. PEARPOINT, Common Sense Tools. MAPS and CIRCLES for Inclusive Education, 2001; http://www.inclusion.com/artcommonsensetools.html (22.01.2019); Krampač, Grljušić, Marinić, Posebno dijete..., 83-90.
} 
odmora. Na taj način osigurana je sistematičnost i dobivena je velika količina informacija. Uključivanjem dva opservatora nastojali smo povećati objektivnost i pouzdanost te smanjiti utjecaj referentnog okvira promatrača, njihovu selektivnost u opažanjima ili opažanje u skladu s očekivanjima.

Provođenje istraživanja, prikupljanje i obrada kvalitativnih podataka dobivenih putem intervjua i opservacije slijedilo je načela Etičkog kodeksa istraživanja s djecom ${ }^{34}$ i Etičkog kodeksa Odbora za etiku u znanosti i visokom obrazovanju. ${ }^{35}$ Dobiveni podatci zaštićeni su sukladno Zakonu o zaštiti osobnih podataka, ${ }^{36}$ a služe isključivo $u$ istraživačke svrhe.

\section{Obrada podataka}

Kvalitativna analiza podataka je definirana kao »metoda istraživanja za subjektivnu interpretaciju pisanog/tekstualnog sadržaja kroz sustavan klasifikacijski proces kodiranja i identifikacije tema ili obrazaca $« .{ }^{37} \mathrm{U}$ ovom istraživanju koristili smo analizu okvira.

»Za razliku od drugih kvalitativnih metoda prikupljanja i analize podataka, kod analize okvira ključne teme za koje želimo dobiti odgovore unaprijed su definirane. Istraživanje se u pravilu provodi jednokratno i u vremenski ograničenom razdoblju. Iako odražava originalna opažanja i refleksije ljudi koji sudjeluju u prikupljanju podatka, prikupljanje podataka je strukturiranije nego što je to tipično za kvalitativna istraživanja, a analiza podatka je jednostavnija.« ${ }^{38}$

Podatke prikupljene kroz polustrukturirani intervju smo transkribirali, nakon čega smo ih postupcima strukturiranja i sažimanja organizirali u kodove i deskriptivne kategorije. Unutar unaprijed određenih tematskih područja (definiranih pomoću istraživačkih pitanja) izlučili smo specifične teme koje ih dodatno objašnjavaju, a koje su opisane kroz pripadajuće kategorije. Vjerodostojnost i pouzdanost istraživanja nastojali smo povećati triangulacijom podataka (dva različita izvora podataka). Svaka je analiza posebno provedena, a za-

\footnotetext{
${ }^{34}$ Usp. DRŽAVNI ZAVOD ZA ZAŠTITU OBITELJI, MATERINSTVA I MLADEŽI, Etički kodeks istraživanja s djecom, (2003), http://www.ufzg.unizg.hr/wp-content/uploads/2013/12/ Eticki-kodeks-istrazivanja-s-djecom.pdf (22.01.2019).

${ }^{35}$ Usp. ODBOR ZA ETIKU U ZNANOSTI I VISOKOM OBRAZOVANJU, Etički kodeks Odbora za etiku u znanosti i visokom obrazovanju, (2006), https://mzo.hr/sites/default/files/links/ eticki_kodeks.pdf (22.01.2019).

${ }^{36}$ Usp. ZAKON O ZAŠTITI OSOBNIH PODATAKA, Narodne novine 103/03, 118/06, 41/08, 130/11, 106/12, https://narodne-novine.nn.hr/clanci/sluzbeni/2012_09_106_2300.html (22.1.2019).

${ }^{37}$ Usp. H. F. HSIEH, S. E. SHANNON, Three approaches to qualitative content analysis, Qualitative health research, 15 (2005) 9, 1277-1288, 1278.

${ }^{38}$ Usp. M. AJDUKOVIĆ, K. URBANC, Kvalitativna analiza iskustva stručnih djelatnika kao doprinos evaluaciji procesa uvodenja novog modela rada u centre za socijalnu skrb, (2010), https://www.google.com/url?sa $=$ t\&rct=j\&q=\&esrc=s\&source=web\&cd=1\&cad=rja\&uact=8\& ved=2ahUKEwiourz86tbhAhVrkIsKHTkkD8MQFjAAegQIARAC\&url=https\%3A\%2F\%2Fhrc ak.srce.hr\%2Ffile\%2F96483\&usg=AOvVaw3ypzGwQCZWKGBB9n26vAif (22.04.2019), 330.
} 
tim objedinjena u rezultate. Podatcima prikupljenim putem opservacije dobilo se niz sekvenci s opisom ponašanja učenika tijekom nastave i odmora. Nakon svake opservacije, promatrači su objedinili zabilješke o ponašanju. Na kraju se izradio sustav kodiranja opažanja u oblik pogodan za uporabu i objedinjavanje s podacima iz intervjua. Kombiniranje intervjua i opservacije omogućilo je bolji uvid u uspješnost MAPS tehnike. Završni je prikaz rezultata dan na uvid i kritički sagledan od nepristrane osobe (psiholog).

\section{Prikaz rezultata i rasprava}

U prikazu rezultata tablično je predstavljeno pet glavnih tematskih područja, a za svako tematsko područje su izlučene specifične teme proizašle iz istraživanja koje su dodatno pojašnjenje i opisane kroz kategorije.

Tablica 1. Prikaz kvalitativne analize podataka tematskog područja Osjećaji sudionika tijekom ostvarivanja dogovorenog akcijskog plana.

\begin{tabular}{|l|l|}
\hline \multicolumn{2}{|c|}{ TEMATSKO PODRUČJE: Osjećaji sudionika tijekom ostvarivanja dogovorenog } \\
akcijskog plana
\end{tabular}

Teme koje su prepoznate u tematskom području Osjećaji sudionika tijekom ostvarivanja dogovorenog akcijskog plana, usmjerene su na osjećaje učenika s teškoćama u razvoju na početku i tijekom druženja. Vršnjaci koji su sudjelovali u ovom istraživanju ističu da je učenik $\mathrm{s}$ teškoćama u razvoju na početku njihova druženja pokazivao jedan od sljedećih osjećaja: zbunjenost, stidljivost, nestrpljivost, uzbuđenost, uznemirenost. Trajanjem druženja učenik se sve više opuštao i pokazivao je osjećaj sreće, ugode, veselja i ponosa. 
Sljedeća prepoznata tema su znakovi iskazivanja osjećaja učenika s teškoćama u razvoju. Učenik je svoje osjećaje iskazivao nasmiješenim izrazom lica, hodanjem po prostoriji, pljeskanjem rukama, sjajem u očima, glasnim smijanjem, smijanjem do suza, lupkanjem rukama o noge, skakutanjem na mjestu, hvaljenjem o druženju, davanjem petice (rukom), zagrljajem, brzim hodanjem, humorom i pjevanjem. Sam učenik, za koga se provodio akcijski plan, naveo je: stidljivost, uzbuđenost, sreća, ugoda i veselje. Znakovi kojima je on iskazivao svoje osjećaje: smijanje, grljenje i pjevanje.

Sljedeće dvije teme usmjerene su na osjećaje vršnjaka na početku i tijekom druženja. Vršnjaci ističu da su se na početku druženja osjećali sretno, da su bili uzbuđeni, veseli, nestrpljivi i iznenađeni. Jedan vršnjak ističe da se na početku druženja osjećao neobično. Tijekom druženja osjećaji vršnjaka nisu se mijenjali velikim intenzitetom. Vršnjaci ističu da su se osjećali sretno, veselo, ugodno, nestrpljivo, ali i da su uživali tijekom druženja i da su u konačnici bili zadovoljni.

Posljednja tema ovog područja usmjerena je na osjećaje roditelja nakon ostvarenog akcijskog plana koje oni opisuju kao radost i oduševljenost.

Tablica 2. Prikaz kvalitativne analize podataka tematskog područja Shvaćanje dogovorenog akcijskog plana.

\begin{tabular}{|l|l|}
\hline \multicolumn{2}{|c|}{ TEMATSKO PODUČJE: Shvaćanje dogovorenog akcijskog plana } \\
\hline \multicolumn{1}{|c|}{ Teme } & \multicolumn{1}{c|}{ Kategorije } \\
\hline $\begin{array}{l}\text { Karakteristike uloge u osobno } \\
\text { usmjerenom planiranju }\end{array}$ & $\begin{array}{l}\text { jasna uloga, podijeljene uloge, uloga zahtijeva odgovornost, } \\
\text { lako ostvariva }\end{array}$ \\
\hline Način ostvarivanja uloge & $\begin{array}{l}\text { druženjem, iniciranjem komunikacije, održavanjem } \\
\text { komunikacije, ponavljanjem verbalnog sadržaja }\end{array}$ \\
\hline
\end{tabular}

U tematskom području Shvaćanje dogovorenog akcijskog plana prepoznata je tema karakteristike uloge u osobno usmjerenom planiranju. Sudionici (roditelji, vršnjaci, pomoćnik u nastavi, učitelji) ističu da im je tijekom procesa ostvarivanja dogovorenog akcijskog plana bila jasna njihova uloga. Ono što im je olakšalo ostvarivanje dogovorenog akcijskog plana jest međusobna podijeljenost uloga. Sudionici navode da su svjesni da njihova uloga zahtijeva odgovorno ponašanje te smatraju da im je uloga bila lako ostvariva. Pokazala se potreba za otvaranjem teme način ostvarivanja uloge, gdje vršnjaci navode da su svoju ulogu ostvarili druženjem s učenikom, iniciranjem i održavanjem komunikacije te ponavljanjem verbalnog sadržaja u trenutcima kada na njih učenik nije obraćao pozornost. 
Tablica 3. Prikaz kvalitativne analize podataka tematskog područja Doprinos dogovorenog akcijskog plana.

\begin{tabular}{|c|c|}
\hline \multicolumn{2}{|c|}{ TEMATSKO PODRUČJE: Doprinos dogovorenog akcijskog plana } \\
\hline Teme & \begin{tabular}{|c|} 
Kategorije \\
\end{tabular} \\
\hline $\begin{array}{l}\text { Promjene u ponašanju } \\
\text { tijekom nastave }\end{array}$ & $\begin{array}{l}\text { - veća uključenost učenika u radionice } \\
\text { - samoinicijativno pružanje podrške vršnjaka tijekom radionica } \\
\text { - samoinicijativno biranje učenika za predstavljanje razreda }\end{array}$ \\
\hline $\begin{array}{l}\text { Promjene u ponašanju } \\
\text { tijekom odmora }\end{array}$ & $\begin{array}{l}\text { - učestalije boravljenje u blizini vršnjaka } \\
\text { - učestalije stupanje u interakciju s vršnjacima putem dodira (daj } \\
\text { pet) } \\
\text { - učestalije stupanje u interakciju s vršnjacima prepričavanjem } \\
\text { druženja } \\
\text { - učestalije stupanje u interakciju s vršnjacima pričajući o druženju } \\
\text { koje slijedi } \\
\text { - učestalije stupanje u interakciju s vršnjacima prepričavanjem } \\
\text { nekog događaja nevezanog uz druženje } \\
\text { - učestalije pokazivanje inicijative za ponovnim druženjem } \\
\text { - smanjeno provođenje vremena u blizini pomoćnice u nastavi } \\
\text { - veća prihvaćenost od strane vršnjaka } \\
\text { - veći odgovor vršnjaka na učenikove potrebe }\end{array}$ \\
\hline $\begin{array}{l}\text { Promjene u ponašanju u } \\
\text { slobodno vrijeme }\end{array}$ & $\begin{array}{l}\text { - sretniji } \\
\text { - prepričavanje druženja } \\
\text { - pričanje o druženju koje slijedi }\end{array}$ \\
\hline
\end{tabular}

U tematskom području Doprinos dogovorenog akcijskog plana prepoznate su teme promjene u ponašanju tijekom nastave, tijekom odmora $i$ u slobodno vrijeme. Sudionici (vršnjaci, pomoćnik u nastavi i učitelji) ističu da su vidljive promjene u ponašanju tijekom nastave. Učenik pokazuje veću uključenost u radionice, ali i da ostali učenici samoinicijativno pružaju podršku tijekom njihove provedbe te samoinicijativno biraju učenika za predstavljanje razreda. Sudionici (učenici, učitelji, pomoćnik u nastavi) ističu da su vidljive promjene u ponašanju tijekom odmora. Učenik učestalije boravi u blizini vršnjaka te češće stupa u interakciju s vršnjacima putem dodira (daj pet), prepričavanjem druženja, pričajući o druženju koje slijedi i prepričavanjem nekog događaja nevezanog uz druženje. Nadalje, uočeno je češće pokazivanje inicijative za ponovnim druženjem te smanjeno provođenje vremena u blizini pomoćnice u nastavi. Od strane vršnjaka je uočena veća prihvaćenost i bolji odgovor na njegove potrebe. Roditelji ističu da su uočili da je učenik sretniji, da češće prepričava druženja te da priča o druženju koje slijedi. Na temelju opservacija učenika s teškoćama $\mathrm{u}$ razvoju tijekom nastavnog procesa i odmora, uočene su promjene ponašanja koje su naveli i sami sudionici. Učenik za kojeg se planiranje provodi, govori da se više druži s vršnjacima te njihova druženja rado prepričava, a svako novo uzbuđeno iščekuje. 
Tablica 4. Prikaz kvalitativne analize podataka tematskog područja Ostvarivanje dogovorenog akcijskog plana.

\begin{tabular}{|l|l|}
\hline \multicolumn{2}{|c|}{ TEMATSKO PODRUČJE: Ostvarivanje dogovorenog akcijskog plana } \\
\hline \multicolumn{1}{|c|}{ Teme } & \multicolumn{1}{c|}{ Kategorije } \\
\hline $\begin{array}{l}\text { Tijek ostvarivanja akcijskog } \\
\text { plana }\end{array}$ & $\begin{array}{l}\text { izvrsna provedba; vrlo organizirano i sistematično; jasne sve } \\
\text { uloge u ostvarivanju dogovorenog akcijskog plana }\end{array}$ \\
\hline $\begin{array}{l}\text { Doprinos akcijskog plana } \\
\text { novim ciljevima }\end{array}$ & $\begin{array}{l}\text { samostalno organiziranje druženja s vršnjacima; kupnja } \\
\text { vikendice }\end{array}$ \\
\hline
\end{tabular}

U tematskom području Ostvarivanje dogovorenog akcijskog plana prepoznata je tema tijek ostvarivanja akcijskog plana. Roditelji ističu da je sam proces izvrsno proveden i da je dogovoreni akcijski plan bio vrlo organiziran i sistematičan te da im je uloga bila jasna. U ovom području otvorila se tema doprinos akcijskog plana novim ciljevima. Upravo je dogovoreni akcijski plan potakao roditelje na što bržu realizaciju usmjerenu na kupnju vikendice izvan grada radi njezina uređenja za igru i druženje, kako obiteljska tako i prijateljska. Valja naglasiti da su roditelji samostalno nastavili organizirati druženja učenika s vršnjacima.

Tablica 5. Prikaz kvalitativne analize podataka tematskog područja Očekivanja u odnosu na dogovoreni akcijski plan.

\begin{tabular}{|c|l|}
\hline \multicolumn{2}{|c|}{ TEMATSKO PODRČJE: Očekivanja u odnosu na dogovoreni akcijski plan } \\
\hline Teme & \multicolumn{1}{c|}{ Kategorije } \\
\hline Realizacija očekivanja & $\begin{array}{l}\text { ostvaren dogovoreni akcijski plan; realiziran dogovoreni akcijski } \\
\text { plan; dogovoreni akcijski plan ostvaren i više od očekivanog }\end{array}$ \\
\hline
\end{tabular}

U tematskom području Očekivanja u odnosu na dogovoreni akcijski plan prepoznata je tema realizacija očekivanja. Sudionici (roditelji, pomoćnik u nastavi, učitelji) ističu da se dogovoreni akcijski plan ostvario, da je on realiziran te da je ostvaren i više od očekivanog.

\section{Zaključna razmatranja}

Vodeći se edukacijskim uključivanjem (inkluzijom), obvezni smo uvoditi promjene u školskom sustavu da bi se zadovoljile individualne potrebe svakog učenika, omogućio razvoj njihovih najjačih strana i stvorilo okruženje koje slijedi koncept dječjih i ljudskih prava. ${ }^{39}$ Proces planiranja podrške u našem odgojno-obrazovnom sustavu do sada nije dosegnuo zadovoljavajuću razinu. Potrebno je stoga kontinuirano raditi na promjeni podrške koja je programsko i formalno-sustavno usmjerena prema podršci koja je orijentirana na izgradnju

\footnotetext{
${ }^{39}$ Usp. Krampač-Grljušić, Socijalno-emocionalna..., 2.
} 
uzajamnih odnosa između svih osoba važnih za samog učenika s teškoćama u razvoju.

Ovako osobno usmjereno planiranje u školi osigurava da ključni dionici, uključujući i roditelje i djecu, budu u mogućnosti odgovoriti na pitanja specifična za inkluziju - kako osigurati razumnu prilagodbu s rezultatom da je fokus pomaknut s pozicije »uključivanje radi uključivanja« (jer tako nalažu propisi), prema aktivirajućem stavu "pogledajmo što zajedno možemo učiniti«. Naše istraživanje je u suglasnosti $\mathrm{s}$ istraživanjem koje je provela Mortier sa suradnicima, ${ }^{40}$ a koje je pokazalo vrijednost takve orijentiranosti te ukazalo na važnost participacije djece s teškoćama u razvoju u planiranju, praćenju i odlučivanju o individualnom planu podrške. Aktivna participacija djece u životu zajednice ključna je za izgradnju solidarnog, uključujućeg i demokratskog društva.

U hrvatskom odgojno-obrazovnom zakonodavstvu ne postoji odredba koja bi izrijekom uređivala obvezu sudjelovanja djece primjerice pri planiranju, izradi i pružanju djelotvornih individualiziranih mjera podrške. Pravilnikom ${ }^{41}$ je propisano da prilagodba programa i individualizirani postupci trebaju biti razrađeni kao pisani dokument koji izrađuju učitelji/nastavnici u suradnji sa stručnim suradnicima škole i daju ga na uvid roditelju/skrbniku. Aktivno sudjelovanje roditelja djeteta kojeg se taj program tiče, nije niti spomenut, a pogotovo ne djeteta pri izradi programa i planiranju postupaka. Načelno, dakle, inkluzivni koncept odgoja i obrazovanja pada na ispitu iz jednog značajnog segmenta: aktivne participacije onoga o kome se odlučuje.

Ovim istraživanjem omogućeno je dublje razumijevanje primijenjene MAPS tehnike u radu s učenikom s teškoćama u razvoju kao i jasniji uvid u ostvarene promjene na željenom području sukladno postavljenom individualnom akcijskom planu. U odnosu na postavljeni cilj istraživanja uočili smo da je primjena MAPS tehnike pokazala uspješnom $\mathrm{s}$ obzirom na pozitivan učinak $u$ odnosu na dobrobit i kvalitetu življenja učenika s teškoćama u razvoju. To smo uočili kroz veću prihvaćenost učenika u razrednom okruženju, razvoj učenikovih socijalnih i komunikacijskih vještina, učvršćivanje prijateljstava i učestalije druženje u slobodno vrijeme. Sve to će pridonijeti lakšoj prilagodbi učenika na zahtjeve koje postavljaju viši razredi osnovne škole. Osobno usmjereno planiranje se pokazalo uspješnim i u odnosu na učenike tipičnog razvoja s obzirom da je uočena povećana empatija za učenika s teškoćama u razvoju te povećanje samoinicijative za uključivanjem učenika s teškoćama u zajedničke aktivnosti. Učenici su iskazali zadovoljstvo mogućnošću sudjelovanja, dodijeljenim im ulogama i provedenim planom. Opisana studija slučaja u ovom radu polazi od idiografskog pristupa u okviru kvalitativne metodologije. Prednost je ovog rada izučavanje učenika s višestrukim teškoćama u razvoju u njegovom prirodnom

\footnotetext{
${ }^{40}$ Usp. Mortier i sur., Participatie van..., 319-330.

${ }^{41}$ Usp. MZOŠ, Pravilnik o osnovnoškolskom...
} 
okruženju. U radu se nastojalo na smislen način protumačiti opažane fenomene koji se temelje na osobnim iskustvima, MAPS akcijskom planu, opažanjima i intervjuima. Ovakav pristup omogućio je dubinski i holistički pristup ispitivanju specifičnog slučaja. Putem različitih metoda i izvora podataka dobili su se vrijedni uvidi u razumijevanju slučaja.

Ovo nam istraživanje pokazuje pozitivne učinke primjene MAPS tehnike i primjer je dobre prakse pružanja podrške učenicima s teškoćama u razvoju u osnovnoškolskom sustavu. Osim navedenih prednosti, provedeno istraživanje ima i neka ograničenja. Ključno ograničenje je to što je analizom proučavan samo jedan slučaj, a što se opravdava jedinstvenošću toga slučaja. Budući da svrha kvalitativnih istraživanja i nije uopćavanje rezultata, generalizacija dobivenih rezultata nije moguća. U smjernice za buduća istraživanja važnim smatramo navesti da bi bilo poželjno uzeti u obzir i druge izvore i metode prikupljanja podataka, kao što su različiti dokumentacijski izvori poput medicinske dokumentacije, analize radova učenika, nalaza i mišljenja različitih stručnjaka, sociometrijske analize razreda i slično. Osim korištenih metoda intervjua i opažanja, bilo bi poželjno napraviti i analizu sadržaja različitih materijala učenika (pisanih, slikovnih) da bi se dobio što bolji uvid u osobine i karakteristike učenika radi što boljeg planiranja i pripreme provođenja akcijskog plana. Također bi bilo korisno ovakav akcijski plan provesti u nekoliko navrata kontinuirano da bi se mogle pratiti nastale promjene tijekom vremena, kao i učinkovitost samog akcijskog plana u svim praćenim aspektima. Na ovakav način bi se dobili i uvidi o tome je li potrebno nešto mijenjati u samoj provedbi i strukturi akcijskog plana.

Neovisno o ograničenjima, zaključno možemo utvrditi da je provedeno istraživanje dalo uvid u važnost primjene MAPS tehnike kao načina individualizirane potpore, naglasilo važnost participacije učenika s teškoćama, vršnjaka i svih važnih osoba iz učenikova prirodnog i neposrednog okruženja. Smatramo da će opisana primjena i procjena uspješnosti MAPS tehnike biti poticaj za širu zastupljenost ovog načina osobno usmjerenog planiranja u hrvatskom osnovnoškolskom sustavu. 
Tanja Opačak* - Aleksandra Krampač-Grljušić*** Marija Lončarić***** Participation of Students Through the Implementation of MAPS Technique of Person-Centered Planning

\section{Summary}

Within the frame of the concept of inclusive education in which the active participation of students with disabilities and individualized support of great importance to educational success and personal satisfaction of students, we applied and evaluated the MAPS technique of person-centered approach to planning for the student of the 5th-grade elementary school. The study was conducted as a case study for a student with disabilities with a total of 14 respondents of whom 10 adults and four fifth grade students. The data were collected through interviews with all participants and observation of the student for whom MAPS was applied. By qualitative data processing, we gained a clearer insight into the subjective experiences and emotions of the participants. Those are divided into 5 thematic areas. A positive contribution to person-centred planning on the quality of life of students with disabilities (greater acceptance of pupils in the classroom environment, development of student social and communication skills, friendship, leisure time) has been noted, which can contribute to the easier adaptation of student to the demands placed by higher classes elementary schools. The conducted research indicates the importance of using MAPS as a way of individualized support for students with disabilities. At the same time, it emphasized the necessity of participation of students with disabilities and their peers in the planning and the implementation of MAPS process. MAPS technique of person-centered planning is a good example of inclusive practice in the general educational system.

Key words: inclusive education, MAPS, participation, person-centered planning.

(na engl. prev. Tanja Opačak)

* Tanja Opačak, PhD student, University of Zagreb, Faculty of Education and Rehabilitation Sciences, University Campus Borongaj; Address: Borongajska cesta 83f, HR-10000 Zagreb, Croatia; E-mail: tanja.opacak@gmail.com.

** Aleksandra Krampač-Grljušić, PhD, Principal, Elementary School Ljudevit Gaj Osijek; Address: Krstova street 99, HR-31000 Osijek, Croatia; E-mail: a.krampac@yahoo.com.

**** Marija Lončarić, mag. rehab. educ., associate expert of Education and Rehabilitation Sciences, Elementary school »Žuti brijeg« Zagreb; Address: Vrtnjakovečka 8, HR-10000 Zagreb, Croatia; E-mail: marija.loncaric92@gmail.com. 